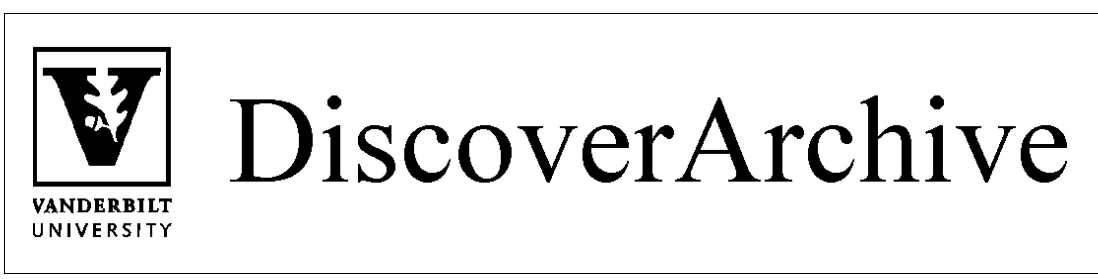

Retrieved from DiscoverArchive,

Vanderbilt University's Institutional Repository

This work was originally published in

18 Sup. Ct. Econ. Rev. 2592010

(C) 2010 by The University of Chicago. All rights reserved. 


\title{
Punitive Damages by Numbers: Exxon Shipping Co. v. Baker
}

\author{
Joni Hersch* and W. Kip Viscusi**
}

The U.S. Supreme Court decision in Exxon Shipping Co. v. Baker is a landmark that establishes an upper bound ratio of punitive damages to compensatory damages of 1:1 for maritime cases, with potential implications for other types of cases as well. This article critiques the Court's reliance on the median ratio of punitive to compensatory damages in samples of verdicts to set an upper bound for punitive damages awards. Our critique of the approach draws on the properties of statistical distributions and a new analysis of cases with punitive damages awards. The Court's conclusion that a 1:1 ratio establishes a fair upper bound lacks a sound scientific basis.

\section{THE U.S. SUPREME COURT DECISION IN EXXON SHIPPING CO. V. BAKER}

The 2008 U.S. Supreme Court decision in Exxon Shipping Co. v. Baker is a landmark both with respect to the setting of punitive damages amounts and with respect to the use of statistical analysis of punitive damages awards to establish guidelines for punitive damages. The thrust of the U.S. Supreme Court decision in Exxon Shipping Co. v. Baker is to reduce the punitive damages award for In re the Exxon Valdez so that there will be a maximum 1:1 ratio of punitive damages

\footnotetext{
* Professor of Law and Economics; Vanderbilt University Law School, 131 21st Avenue South, Nashville, TN 37203. joni.hersch@vanderbilt.edu. (615) 343-7717.

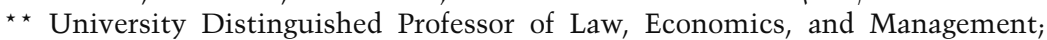
Vanderbilt University Law School, $13121^{\text {st }}$ Avenue South, Nashville, TN 37203. kip.viscusi@vanderbilt.edu. (615) 343-7715.

${ }^{1}$ Exxon Shipping Co v Baker, 128 S Ct 2605 (2008). 
to compensatory damages in this case. The financial implications are substantial, as the original 1994 jury award made in the case In re the Exxon Valdez consists of $\$ 287$ million in compensatory damages and $\$ 5.0$ billion in punitive damages. ${ }^{2}$

Exxon Shipping Co. v. Baker indicates a far lower upper bound ratio than was recommended by the U.S. Supreme Court in its 2003 decision in State Farm v. Campbell. As the Court reviews the implications of the previous decision, it observes: "In State Farm, we said that a single-digit maximum is appropriate in all but the most exceptional cases, and '[w] hen compensatory damages are substantial, then a lesser ratio, perhaps only equal to compensatory damages, can reach the outermost limit of the due process guarantee.' (538 U.S., at 425.)." 3

The potential ramifications of the 2008 decision in Exxon Shipping Co. v. Baker may be far reaching, and the 1:1 upper limit guideline ultimately may not be restricted to maritime shipping cases such as this. As Justice Ginsburg observes in her opinion: "In the end, is the Court holding only that $1: 1$ is the maritime-law ceiling, or is it also signaling that any ratio higher than 1:1 will be held to exceed 'the constitutional outer limit'? ... On next opportunity, will the Court rule, definitively, that $1: 1$ is the ceiling due process requires in all of the States, and for all federal claims?" Given the earlier statements by the Court in State Farm v. Campbell, as well as the Court's reliance in Exxon Shipping Co. v. Baker on statistical analyses of punitive damages that are not specific to maritime cases, there is considerable likelihood that the 1:1 ceiling ultimately will have ramifications beyond maritime cases.

In reaching the conclusion that a $1: 1$ ratio of punitive to compensatory damages is an appropriate upper bound, the Court relies on evidence from cases tried to verdict in which punitive damages had been awarded. The rationale for setting any specific value or range of values for the relationship between punitive awards and compensatory awards follows a rather baffling circular reasoning in that it questions the soundness of current punitive damages awards while at the same time using statistics drawn from these awards to set guidelines for future punitive damages awards.

${ }^{2}$ The compensatory damages reference point used by the U.S. Supreme Court is $\$ 507.5$ million rather than the original $\$ 287$ million verdict because the Court accepted the District Court's calculation of the total compensatory damages. See id at 2605,2622 . The District Court included in the compensatory damages tally the $\$ 287$ million Phase II jury verdict as well as twenty other court awards and settlements to Seattle fish processors, Native class members, Native corporations, municipalities and villages, and other groups harmed by the spill. See In re the Exxon Valdez, $236 \mathrm{~F}$ Supp 2d 1043, 1058-60 (D Alaska 2002).

${ }^{3}$ Exxon Shipping Co, $128 \mathrm{~S}$ Ct at 2622. 
The Court's argument for imposing additional structure is that predictable punitive damages awards are essential for establishing appropriate incentives: "Thus, a penalty should be reasonably predictable in its severity, so that even Justice Holmes's 'bad man' can look ahead with some ability to know what the stakes are in choosing one course of action or another." ${ }^{\prime 4}$

The Court concludes that current punitive damages awards are not sufficiently predictable, so additional guidelines are needed: "The real problem, it seems, is the stark unpredictability of punitive awards. Courts of law are concerned with fairness as consistency, and evidence that the median ratio of punitive to compensatory awards falls within a reasonable zone, or that punitive awards are infrequent, fails to tell us whether the spread between high and low individual awards is acceptable. The available data suggests it is not." ${ }^{\prime \prime}$ The Court then adopts its 1:1 ratio of punitive damages awards to compensatory damages awards from the very behavior it claims is unpredictable.

Not only does the Court make use of observed punitive damages awards, it does so in a completely arbitrary fashion. The logic the Court relies on is that the median of the ratio of punitive damages to compensatory damages is a reasonable benchmark; that the median ratio in studies cited is around $0.65: 1$; and therefore, a ratio of $1: 1$ is "a fair upper limit." ${ }^{16}$ Yet, there are many other statistical reference points that could have been chosen, including those that also are based on an analysis of whether there were legitimate reasons for different ratios.

In this article, we analyze the statistical support for the Court's decision and present new evidence relevant to the potential implications of the decision. First, we review law and economics theory demonstrating that while predictability of punitive damages awards is desirable, the ratio should depend on the probability of detection. The efficient economic ratio could be greater than 1:1, less than 1:1, or some other value. Second, given the experimental evidence and the Court's conclusion that punitive damages awards are unpredictable, the Court's reliance on observed patterns of punitive damages to set guidelines for permissible punitive damages awards is highly questionable.

Our third concern is whether using the median ratio is a sensible approach. As the ratio consists of two positive numbers, ratio values can never be negative. For a truncated distribution of this type, one would expect the mean ratio to exceed the median so that a disparity between the mean and median values is not a signal of unpredictabil-

\footnotetext{
${ }^{4}$ See id at 2618.

${ }^{5}$ See id at 2617.

${ }^{6}$ See id at 2621.
} 
ity, but is a consequence of the inherent mathematical constraints on the distribution.

Fourth, we present a review of very large punitive damages awards and a detailed analysis of the data that form the primary empirical basis for the Court's opinion, the Civil Justice Survey of State Courts [hereinafter CJSSC]. While the sample of extremely large punitive damages awards provides evidence of highly variable ratios of punitive damages to compensatory damages, the implications of the CJSSC data relied upon by the Court are less supportive of the Court's argument. By analyzing the CJSSC data by case type and through a multiple regression analysis rather than focusing on overall averages, we are able to obtain a more accurate perspective than that offered by the Court. For the most part, there is a reasonable relationship between the mean and median ratio values. Only a small fraction of cases have awards in excess of the 1:1 ratio, and the main reason for these high ratios is that these cases have very low compensatory damages amounts.

\section{THE ECONOMIC BASIS FOR PUNITIVE DAMAGES AWARDS}

In framing the punitive damages issue, the Court recognizes the different roles of compensatory damages and punitive damages, but provides no explicit theoretical basis for their relationship. In particular, the Court indicates that the function of punitive damages is restricted to retribution and deterrence rather than a compensatory function. ${ }^{7}$ With respect to deterrence, the Court also acknowledges the law and economics perspective that the punitive damages ratio could be higher for cases in which it is difficult to detect the wrongdoing. ${ }^{8}$ The efficient level of total damages from the standpoint of the economic theory of deterrence is the economic value of the harm divided by the probability of detection. ${ }^{9}$ Given that there is no chance

${ }^{7}$ Id at 2615.

${ }^{8}$ See id.

${ }^{9}$ The central role of the probability of detection in the law and economics approach dates back to Jeremy Bentham and is explored in detail in A. Mitchell Polinsky \& Steven Shavell, Punitive Damages: An Economic Analysis, 111 Harv L Rev 869-962 (1998). The basic law and economics theory of the optimal deterrence value of punitive damages can be recast in terms of the ratio of punitive damages to compensatory damages. Suppose that the probability of detection is $\mathrm{q}$. Then, to provide efficient incentives for the wrongdoer to exercise care, the condition for optimal damages levels is that

Compensatory Damages + Punitive Damages $=$ Harm $/ \mathrm{q}$,

which can be rewritten as

$\mathrm{q} \times($ Compensatory Damages + Punitive Damages $)=$ Harm. 
of failing to detect a massive oil spill, the probability of detection for this case is $1.0 .^{10} \mathrm{Had}$ the Court restricted its approach to the standard law and economics reasoning with respect to detection, from the standpoint of deterrence the optimal punitive damages amount would have been zero. The Court also discusses other purposes of punitive damages, such as a retribution objective. Our intent here is not to offer an alternative theory of punitive damages, but to examine the legitimacy of the statistical basis for the Court's decision.

The Court's ultimate recommendation of a 1:1 ratio of punitive damages to compensatory damages for maritime cases stems from a desire to impose discipline on the setting of punitive damages by establishing an upper bound on the ratio of punitive damages to compensatory damages. The Court selects its upper bound ratio of punitive damages to compensatory damages based on the median ratios reported in empirical studies. With empirical evidence across samples of cases indicating a median ratio less than $1: 1$, and often in a range such as $0.65: 1$, the Court concludes that a ratio of $1: 1$ in this case would be appropriate:

On these assumptions, a median ratio of punitive to compensatory damages of about $0.65: 1$ probably marks the line near which cases like this one largely should be grouped. Accordingly, given the need to protect against the possibility (and the disruptive cost to the legal system) of awards that are unpredictable and unnecessary, either for deterrence or a measure of retribution, we consider that a 1:1 ratio, which is above the median award, is a fair upper limit in maritime cases. ${ }^{11}$

Whether the median is a useful guide and whether such a punitive damages upper bound ratio will restrain damages is examined below.

To the extent that the Court recognizes the theoretical bases of punitive damages, it is with respect to exceptions from the recommended 1:1 ratio. Specifically, the Court concludes:

The expected penalty given by multiplying the probability of detection by the sum of compensatory and punitive damages will provide efficient incentives for exercising care if that value equals the cost of the harm. If the harm is fully reimbursed by the value of compensatory damages so that Harm equals Compensatory Damages, then this condition can be rewritten as

Punitive Damages $/$ Compensatory Damages $=(1 / \mathrm{q})-1$.

${ }^{10}$ More generally, ascertaining the ex ante probability of detection may be difficult because the cases that go to court are the ones for which the wrongful conduct has been detected.

${ }^{11}$ Exxon Shipping Co, $128 \mathrm{~S}$ Ct at 2621-22. 
In a well-functioning system, we would expect that awards at the median or lower would roughly express jurors' sense of reasonable penalties in cases with no earmarks of exceptional blameworthiness within the punishable spectrum /cases like this one, without intentional or malicious conduct, and without behavior driven primarily by desire for gain, for example) and cases (again like this one) without the modest economic harm or odds of detection that have opened the door to higher awards. ${ }^{12}$

Factors such as a low probability of detection and intentional and malicious conduct may enter in justifying deviations from the 1:1 guidelines, but are not themselves incorporated in setting this guideline. Moreover, how and to what extent these factors should be applied in deviating from the 1:1 ratio is never discussed.

\section{CURRENT PUNITIVE DAMAGES AWARDS AS A REFERENCE POINT}

In its focus on the ratio of punitive damages to compensatory damages, the Court at least implicitly acts under the assumption that observed punitive damages awards provide some form of meaningful guidance. The Court does not address the issue of whether there is any rationale for relying on observed decisions for guidance in setting appropriate punitive damages amounts. In this section, we question the legitimacy of the Court's approach. In the following discussion, we refer to juries as setting the award amounts because the majority of punitive awards are outcomes of jury trials rather than bench trials.

The Court's view that the problem with punitive awards is their "unpredictability" is consistent with recent experimental research on jury behavior reported in Sunstein et al. ${ }^{13}$ The Court does not offer guidance that would enable juries to approach the setting of punitive

\footnotetext{
${ }^{12} \mathrm{Id}$.

${ }^{13}$ The Court notes that it chose not to rely on the studies reported in Cass R. Sunstein, et al, Punitive Damages: How Juries Decide (University of Chicago Press, 2002): "Because this research was funded in part by Exxon, we decline to rely on it." However, we note that the book was peer reviewed and also summarizes research that is published in peer-reviewed journals. In addition, many of the results with respect to punitive damages are simply variants of well established patterns of behavior that have been documented in a large literature in behavioral economics and psychology and are uncontroversial within these bodies of literature. Thus, in our opinion, the source of funding does not seem to warrant a wholesale rejection of a body of literature. See Exxon Shipping Co, $128 \mathrm{~S}$ Ct at 2626 n 17.
} 
damages in a way that embodies the functions of punitive damages. It implicitly accepts the current ratio distribution as having sufficient meaning and focuses on the median value of awards of roughly $0.65: 1$ as a useful reference point. The Court adds some additional leeway amount, presumably to capture case heterogeneity, so as to have a 1:1 ratio as "a fair upper limit in such maritime cases." 14

A frequently observed shortcoming of jury behavior is that jurors often seek convenient, salient reference points, taking advantage of available anchors in setting the punitive damages award amount. These anchors could be provided by attorneys as part of their arguments in the case or could come from jurors' experiences. ${ }^{15}$ Based on their studies, Sunstein et al. conclude that jurors engage in a multistage anchor-and-adjust process where they first receive the anchor amount, translate that anchor into an appropriate dollar award, bring to bear additional information about the case, and then adjust the award amount to arrive at their final award value. ${ }^{16}$ The influence of anchor-and-adjustment processes as a crutch for handling complex decisions is a well-established phenomenon in the behavioral literature and is not restricted to punitive damages. ${ }^{17}$

Likewise, the Court apparently searched for an available anchor to resolve its complex task. The Court sought refuge in a salient statistical value-the median ratio in samples of observed cases. Much like the punitive damages anchors given to juries, the median statistic looms as a reference point that could assist the Court in resolving an otherwise difficult task. Reliance on such anchors by either jurors or the Court reflects the absence of a more systematic methodology for establishing the punitive damages value or the appropriate ratio of punitive damages to compensatory damages.

The broader implication of the experimental studies of punitive damages is that the task of setting punitive damages is fraught with potential errors and systematic biases. ${ }^{18}$ Examining any statistic from the current distribution of the ratio of punitive damages to compensatory damages is only meaningful if the underlying juror

${ }^{14}$ Exxon Shipping Co, $128 \mathrm{~S} \mathrm{Ct}$ at $2626 \mathrm{n} 17$.

${ }^{15}$ A plaintiff attorney's request for a specific damages amount can influence punitive damages awards even when juries have explicit jury instructions that presumably enable them to avoid anchoring effects. See Sunstein, et al, at 149-58 (cited in note 13$)$.

${ }^{16}$ See id at 216-19.

${ }^{17}$ Thomas D. Wilson, et al, A New Look at Anchoring Effects: Basic Anchoring and Its Antecedents, 125 J Experimental Psychol Gen 387 (1996).

${ }^{18}$ To the extent that the biases are systematic and not random, statistical examinations of actual patterns of jury awards to assess their predictability, or lack thereof, are off point. If jury awards are always an order of magnitude too high because of anchoring effects, they will be predictable, but wrong. 
behavior is sound. The Court fails to grapple with the fundamental inadequacies of the process for setting the award amounts and never motivates the rationale for establishing punitive damages guidelines using statistics drawn from current awards.

\section{THE VALIDITY OF THE COURT'S STATISTICAL REFERENCE POINT}

In this section, we discuss the Court's use of the median as a statistical reference point and the suitability of the sample of cases that the Court relies upon in setting the punitive damages guideline. Given the properties of the distribution of ratios of punitive damages to compensatory damages, we suggest that the median is an overly conservative upper bound on the ratio. Furthermore, the studies cited by the Court are not based on the high stakes cases of the type that have been the subject of Supreme Court review and therefore may not provide the appropriate comparator group.

Both the median and the mean are measures of central tendency in a distribution. In terms of the ratios of interest here, for an odd number of cases, the median ratio will have an equal number of cases with ratios below the median ratio and above the median ratio. If there is an even number of cases, the median will be the average of the two ratios in the middle of the distribution. The mean ratio is the simple average of the ratios of punitive damages to compensatory damages across all cases. Thus, the mean is the sum of the ratios divided by the number of cases. The mean consequently takes into account the ratio values for the entire mix of cases, ranging across all types of conduct and harm values. In effect, the median selects a single case from the middle of the distribution as the guide.

Whether the median and mean are the same depends on the shape of the distribution. For symmetric distributions around the mean value, the mean and median will be identical. ${ }^{19}$ However, as the Court notes, for one analysis of data from the CJSSC, the mean ratio value is $2.90: 1$, which is much greater than the median value of $0.62: 1$. The Court concludes that this difference, along with the observed standard deviation of ratios of 13.81 , is a sign that ratios are unpredictable..$^{20}$

A difference between the mean and median coupled with a positive standard deviation does not imply that the ratios of punitive awards to compensatory awards are unpredictable. Suppose that

\footnotetext{
${ }^{19}$ Jeffrey M. Wooldridge, Introductory Econometrics: A Modern Approach 708 (2d ed, South-Western 2003).

${ }^{20}$ Exxon Shipping Co, $128 \mathrm{~S} \mathrm{Ct}$ at 2617.
} 
there are ten cases in each of three categories of recklessness. Cases with a low degree of recklessness have a ratio of 0.10 , cases with a medium degree of recklessness have a ratio of 0.62 , and cases with a high degree of recklessness have a ratio of 10 . These cases have a median ratio of 0.62 , a mean ratio of 3.57 , and a standard deviation of 4.63. While the ratios are clearly different, the outcomes are perfectly predictable conditional on the degree of recklessness in the case.

The Court also makes an unwarranted logical leap in concluding that variability in the ratio of punitive damages to compensatory damages implies that punitive damages award levels are unpredictable. ${ }^{21}$ Suppose that in every case the punitive damages award is $\$ 1,000$. Even with perfectly predictable punitive damages levels, the ratios will exhibit variation because the denominator in the ratiothe value of compensatory damages-differs across cases.

The Court's conclusion about unpredictability also ignores the quite legitimate reasons for why the mean might exceed the median given the constraints on the possible shapes of the distribution of ratios. It is not at all surprising or indicative of unpredictable awards that the mean ratio is greater than the median ratio. The distribution of possible ratios is truncated from below at zero so that one would expect a relatively longer upper tail of the distribution. A symmetric distribution requires similar massing of the observed ratios above and below the median. For the distribution to be symmetric around a median value of 0.62 , the lowest observed ratio of zero would need to be coupled with the highest observed ratio of 1.24. Surely there are valid reasons that one might observe the ratio of punitive damages to compensatory damages above 1.24. More generally, one would expect there to be an asymmetry in the ratio distribution, given that the ratio values are constrained to be positive, so that the mean ratio will exceed the median ratio.

The Court's focus on the median is presumably an attempt to limit the influence of extreme outliers. However, the fact that the median is below the mean does not necessarily signal the presence of outliers or the need to disregard mean ratio values that are more reflective of the broader relationship between punitive damages and compensatory damages. Other procedures, such as trimming the top 5\% and bottom $5 \%$ of the distribution, can eliminate the influence of outliers at both ends of the distribution. By selecting the median rather than the mean as the key benchmark of interest, the Court adopts a highly constraining approach.

We now turn to the representativeness of the data relied upon by the Court. The Court considers the findings of several studies in the

${ }^{21}$ Id. 
literature. The broadest data source used in the cited studies is the CJSSC, with data from 1992, 1996, and 2001..$^{22}$ The Court focuses primarily on studies based on these data. The second set of studies uses data from cases in particular regions of the country, including San Francisco and Cook Counties from the early 1980s through the early 1990s, ${ }^{23}$ and Florida state courts from 1989 to $1998 .{ }^{24}$ The third set of studies uses data from financial injury cases in six states and in Cook County. ${ }^{25}$ The median ratios of punitive damages to compensatory damages in these studies ranged from $0.62: 1$ to $0.67: 1$, with the exception of a ratio of 1.4:1 for a financial harm sample. Because the Court focuses primarily on the implications of the CJSSC data in arriving at its decision in Exxon Shipping Co. v. Baker, our current discussion focuses on these data, although the implications are general. In the following section, we also provide a new analysis of these data.

A brief overview of the data collection procedure used for the CJSSC is useful. ${ }^{26}$ The CJSSC is a sample of tort, contract, and real property cases tried to verdict in selected counties in state courts. Thus, cases that settle, cases tried in state courts but in counties not in the sampling frame, and cases tried in federal courts are not represented. There are currently three waves of data that are publicly available, with samples of cases completed in 1992 (jury only), and in 1996 and 2001 (both jury and bench trials). ${ }^{27}$

${ }^{22}$ See Theodore Eisenberg, et al, Juries, Judges, and Punitive Damages: Empirical Analyses Using the Civil Justice Survey of State Courts 1992, 1996, and 2001 Data, 3 J Empirical Legal Stud 278 (2006); Dept. of Justice, Bureau of Justice Statistics, Thomas H. Cohen, Punitive Damage Awards in Large Counties, 2001 (2005). For an analysis of the Civil Justice Survey of State Courts 1996, not cited in the Court's opinion, see Joni Hersch and W. Kip Viscusi, Punitive Damages: How Judges and Juries Perform 33 J Legal Stud 1, 1-36 (2004).

${ }^{23}$ See RAND Institute for Civil Justice, Deborah R. Hensler and Erik Moller, Trends in Punitive Damages: Preliminary Data from Cook County, Illinois, and San Francisco, California (1995); RAND Institute for Civil Justice, Mark A. Peterson, Syam Sarma, and Michael G. Shanley, Punitive Damages: Empirical Findings (1987).

${ }^{24}$ See Neil Vidmar and Mary R. Rose, Punitive Damages by Juries in Florida: In Terrorem and in Reality, 38 Harv J Legis, 487, 487-513 (2001). For details see Exxon Shipping Co, $128 \mathrm{~S}$ Ct at 2625 n 13.

${ }^{25}$ See Erik Moller, Nicholas M. Pace, and Stephen J. Carroll, Punitive Damages in Financial Injury Jury Verdicts, 28 J Legal Stud 307 (1999).

${ }^{26}$ The discussion below is based on the U.S. Dept. of Justice, Bureau of Justice Statistics, Inter-university Consortium for Political and Social Research, Civil Justice Survey of State Courts, 2001: United States, (1st ICPSR ed, 2004).

${ }^{27}$ A fourth wave of data was made publicly available after this article was completed. The sampling frame is a two-stage stratified sampling process. In the first stage, the 75 most populous counties were identified. In the second stage, 45 of these counties were selected for inclusion in the study. Within the set of counties selected for 
While the CJSSC database is a representative sample given the sampling frame, we now discuss whether evidence from this data set provides appropriate guidance for large stakes cases. As we discuss, the majority of the verdicts in this data set result in small punitive awards and small ratios. In contrast, the two cases that led to the Court's recent guidance with respect to the ratio of punitive awards to compensatory awards involve far higher stakes than all but one case in the CJSSC database.

An alternative data source is the sample of cases with punitive damages awards of at least $\$ 100$ million, which we refer to as the 'blockbuster' sample. ${ }^{28}$ As of 2007, there have been 93 awards that merit the blockbuster designation. These awards of at least $\$ 100$ million are often among the most prominent cases and include the State Farm and Exxon Shipping Co. punitive damages awards that are the focus of the two most recent U.S. Supreme Court decisions pertaining to punitive damages. ${ }^{29}$ In addition, the economic stakes involved are quite substantial and are more similar to the large stakes cases that merit U.S. Supreme Court review.

To what extent is the CJSSC dataset reflective of these large punitive damages awards? In all, eighteen blockbuster awards were in federal courts-19 percent of the total number of blockbuster awards, including the 1994 Exxon Valdez oil spill award in In re the Exxon Valdez-the case that gave rise to the U.S. Supreme Court decision in Exxon Shipping Co. v. Baker. Within the state courts, the CJSSC sample includes counties in 22 states, so more than half of the states are not eligible for inclusion in the sample. Among the omitted states are Alaska, the site of the Exxon Valdez oil spill, and Mississippi and Alabama, two states widely reputed to be favorable venues for

inclusion in the study, cases that met certain criteria were included in the data set. The survey included all trials in the county if there were fewer than 300 total trials or 300 jury trials in the county. If there were more than 300 cases, a random sample of 275 cases of each trial type were included in the sample, as well as all medical malpractice or products liability cases.

${ }^{28}$ Procedures for constructing this comprehensive inventory of all large punitive damages awards are described in Hersch \& Viscusi, 33 J Legal Stud 1 (cited in note 22), and in W. Kip Viscusi, The Blockbuster Punitive Damages Awards, 53 Emory L J 1405 (2004). These articles report the list of all blockbuster cases through 2003. The same procedures used in constructing the earlier punitive damages compilation have been followed to include all cases through 2007. This expanded set of cases forms the basis for the current discussion.

${ }^{29}$ The original punitive damages verdicts are $\$ 145$ million in the State Farm case and $\$ 5$ billion in the Exxon case. Earlier U.S. Supreme Court decisions address smaller punitive damages awards, which nevertheless would be at the very high end of the state court sample distribution. The punitive damages award in BMW of N Am, Inc $v$ Gore, 517 US 559 (1996) is $\$ 4$ million, while the punitive damages award in Cooper Industries, Inc v Leatherman Tool Group, Inc, 532 US 424 (2001) is \$2 million. 
punitive damages. The $B M W v$. Gore case that is the subject of an earlier U.S. Supreme Court decision on punitive damages involves an Alabama damages claim.

For many states, only the single most populous county is included. Thus, for Illinois, Cook County is in the data set, while the highly controversial downstate venue of Madison County is not. ${ }^{30}$ Two of the blockbuster awards are in Madison County, as compared to only one in the more populous Cook County. ${ }^{31}$ In terms of the number of blockbuster awards omitted, the incomplete county coverage of the CJSSC data set is more important than the state omission, as 25 of the 67 awards are in counties for which the state is in the sample, but the county is not.

Had the Court used the blockbuster cases as the reference point, it would have reached a quite different assessment of the ratio of punitive damages to compensatory damages. Excluding a case for which the ratio is not defined because the compensatory damages value is zero, the blockbuster awards ratio distribution has a median value of 8.85 , or more than 10 times greater than the median value of $0.65: 1$ focused on by the Court. The blockbuster case ratios are highly variable, with a mean of 757.97 and a standard deviation of 4629.97, which is consistent with the Court's concerns with variability. However, if the solution to variability is to draw on the implications of the median ratio, then a median based on high stakes cases may be more pertinent than the median for a mix of cases that often includes small punitive damages awards, as we document below. Using a high stakes case median ratio would lead to a greater permissible level of punitive damages.

\section{VARIATION IN PUNITIVE DAMAGES RATIOS}

The decision in Exxon Shipping Co. recognizes that there is variability in punitive damages awards. The discussions of the ratios' mean-median spread and the standard deviation of award ratios were

\footnotetext{
${ }^{30}$ See Amalia Deligiannis, Madison County: A Corporation's Worst Nightmare, 14 Corp Legal Times 52 (2004); American Tort Reform Association, Bringing Justice to Judicial Hellholes 20033 (2003), online at http://www.atra.org/reports/hellholes/ report.pdf; see also Sue Reisinger, Shell Oil's Hefty Settlement: A Harbinger for MTBE Defendants, 12 Corp Legal Times 54 (2002) (all providing examples of Madison County's reputation).

${ }^{31}$ The two Madison County awards were $\$ 3.1$ billion in Price v Philip Morris, Inc, 341 Ill App 3d 941 (2003) and a \$200 million award in Whittington v US Steel, 2003 WL 24057769 . The Cook County award was a $\$ 124.57$ million punitive damages award in Proctor v Davis and Upjohn Co, 291 Ill App 3d 265 (1997).
} 
two such references to statistical variability. However, the punitive damages awards also might differ for sound substantive reasons. As the Court recognizes, there is a rationale for a higher ratio when there is exceptional blameworthiness, small economic damages, or a low probability of detection. ${ }^{32}$ In this section, we examine the heterogeneity of punitive damages ratios to explore these and other concerns to the extent that the CJSSC data permit. In particular, we analyze three issues: i) whether many punitive damages awards are trivial so that inclusion of these awards generates a lower median value, ii) whether large ratios of punitive damages to compensatory damages are likely to arise when the value of compensatory damages is low, and iii) whether punitive damages vary by case type to reflect the blameworthiness of behavior and other factors that the Court recognizes as legitimate sources of departure from the recommended $1: 1$ ratio.

In doing so, we examine statistics based on the CJSSC for 1992, 1996, and 2001, which is the focus of much of the Court's discussion. For those three years, there are 517 cases in which the plaintiff won and was awarded both positive punitive damages and positive compensatory damages. We refer to this set of 517 cases as the "punitive damages sample." All values reported in the text and Tables 1 and 2 are weighted by the sample weight provided for each year. ${ }^{33}$ We convert all punitive damages values to 2001 dollars so that data from the three survey years are comparable. We find a median ratio of punitive damages to compensatory damages of 0.66:1 after weighting the observations by the sampling weights. ${ }^{34}$ However, our calculated mean ratio is $22.1: 1$, or almost an order of magnitude greater than the mean value of 2.90 cited by the court. ${ }^{35}$

The first matter of interest is whether many punitive damages awards are very small and whether inclusion of these awards in the sample reference points used by the Court distorts the median ratio of punitive damages to compensatory damages. Imposing a $\$ 1,000$ minimum threshold on punitive damages awards reduces the number of cases with punitive damages awards from 517 to 491 and raises the median ratio from 0.66 to 0.75 . If a minimum punitive damages award of $\$ 10,000$ is imposed, the number of cases is 388 , and the ratio

${ }^{32}$ Exxon Shipping Co, $128 \mathrm{~S}$ Ct at 2621-22.

${ }^{33}$ The specific weighting variables we use are 'wght' for 1992; 'wgt2' for 1996; and 'wght75' for 2001.

${ }^{34}$ The unweighted median ratio is $0.62: 1$, the same as that reported in Eisenberg, et al, 3 J Empirical Legal Stud 278 (cited in note 22), and cited by the Court. See Exxon Shipping Co, $128 \mathrm{~S}$ Ct at 2617.

${ }^{35}$ Our unweighted mean value of the ratio is $14.16: 1$. The Court cites unweighted values. 
increases to 0.89 . Increasing the minimum punitive damages award to $\$ 100,000$ reduces the number of cases to 199 and boosts the ratio to 1.15 . Consequently, even a punitive damages cutoff well below the magnitude of any punitive damages awards in recent Supreme Court decisions leads to a ratio of at least 1.15, which is above the Court's guideline in Exxon Shipping Co. v. Baker. The Court's decision to use all cases as a reference point rather than considering only the large punitive damages cases alters the distribution in a manner that generates a lower median ratio. These concerns also call into question the appropriateness of relying on the median ratio for all awards as a guideline.

The second issue pertains to the Court's acknowledgement that a very low level of compensatory damages could be a rationale for a high ratio. This relationship is in fact borne out. For example, the thirteen cases with a compensatory damages value below $\$ 1,000$ have a median ratio of 25.67 and a mean ratio of 613.61. The highest ratio in the CJSSC sample is 5,000:1, which is an automobile tort case in which compensatory damages are $\$ 1$ and punitive damages are $\$ 5,000$. Given the minimal value of compensatory damages in this case, such a ratio might well be in line with the Court's willingness to accept higher ratios when compensatory damages are very small. Thus, the presence of some so-called ratio outliers in the observed distribution may stem from a very low level of compensatory damages rather than an implausibly large ratio.

The third issue is whether there might be additional case-specific justifications for a large ratio. Analyzing the entire distribution of ratios by different case type illuminates this issue and reinforces the earlier concern that inclusion of small stakes cases may distort the award distribution in a manner that makes the median a meaningless guide. Table 1 presents the mean of the ratios and the percentile distribution for different case types for the punitive damages sample. ${ }^{36}$ This breakdown makes it possible to examine different portions of the ratio distribution as well as whether the case types differ in terms of their ratio. That there is such a distribution and that it varies by case type highlights two aspects of the Court's statistical approach: i) the Court selected the median as the reference point despite the existence of many other percentiles in the distribution that might be pertinent, and ii) it did not incorporate differences across case types,

${ }^{36}$ The common set of case types that are reported by the CJSSC for all three years are the following: motor vehicle tort, premises liability, products liability, intentional tort, medical malpractice, professional malpractice, slander/libel, other tort, fraud, seller plaintiff, buyer plaintiff, employment contract, lease, other contract, other property. Mortgage and eminent domain are also recorded, but no cases of these types have punitive damages awards within the sample. 
Table 1. Distribution of Ratio of Punitive Damages to Compensatory Damages by Case Type

\begin{tabular}{|c|c|c|c|c|c|c|c|}
\hline \multirow[b]{2}{*}{ Case Type } & \multirow[b]{2}{*}{$\mathrm{N}$} & \multirow[b]{2}{*}{ Mean } & \multicolumn{5}{|c|}{ Percentile } \\
\hline & & & 5 & 25 & 50 & 75 & 95 \\
\hline All case types & 517 & 22.1 & 0.03 & 0.23 & 0.66 & 1.70 & 13.16 \\
\hline Motor vehicle tort & 60 & 135.5 & 0.01 & 0.17 & 0.48 & 1.12 & 7.73 \\
\hline Premises liability & 25 & 2.3 & 0.09 & 0.41 & 1.45 & 1.63 & 6.11 \\
\hline Products liability & 7 & 27.5 & 0.22 & 0.51 & 0.63 & 1.53 & 258.27 \\
\hline Intentional tort & 90 & 21.5 & 0.06 & 0.30 & 0.71 & 1.95 & 68.97 \\
\hline Medical malpractice & 11 & 1.1 & 0.09 & 0.09 & 0.54 & 1.00 & 9.08 \\
\hline Professional malpractice & 12 & 1.3 & 0.00 & 0.17 & 0.68 & 2.02 & 4.63 \\
\hline Slander/libel & 17 & 3.6 & 0.03 & 0.37 & 0.76 & 3.81 & 18.00 \\
\hline Other tort & 37 & 5.2 & 0.08 & 0.29 & 1.29 & 4.41 & 25.67 \\
\hline Fraud & 77 & 1.7 & 0.05 & 0.25 & 0.66 & 1.21 & 5.50 \\
\hline Seller plaintiff & 23 & 1.2 & 0.01 & 0.10 & 0.23 & 1.08 & 6.96 \\
\hline Buyer plaintiff & 51 & 1.7 & 0.05 & 0.19 & 0.56 & 1.73 & 10.00 \\
\hline Employment contract & 63 & 1.6 & 0.07 & 0.33 & 0.64 & 1.83 & 7.55 \\
\hline Lease & 11 & 0.8 & 0.01 & 0.42 & 0.83 & 1.25 & 2.06 \\
\hline Other contract & 25 & 1.9 & 0.05 & 0.29 & 0.95 & 4.05 & 5.38 \\
\hline Other property & 6 & 0.8 & 0.08 & 0.08 & 0.43 & 1.19 & 2.60 \\
\hline
\end{tabular}

Data source: Authors' calculations based on the Civil Justice Survey of State Courts for the years 1992, 1996, and 2001. The sample is comprised of 517 cases where the plaintiff won and compensatory and punitive damages were awarded. All values are weighted by sample weight provided for the data year. Case type is not reported for two cases from 1996. Note that the 5 th percentile and the 25 th percentile for medical malpractice are both 0.09 .

even though the differences in the distributions among case types are often substantial.

Examination by case type indicates that the mean of the ratio of punitive damages to compensatory damages is low for most case types. There is much less variability than is implied by the Court. The mean ratios are below 2:1 for nine of the fifteen case types. The main factors driving the overall spread between mean and median ratios are concentrated in a few types of cases. Motor vehicle tort cases have the highest mean ratio, where this effect is driven by a small group of cases at the upper end of the distribution, such as the $\$ 1$ compensatory damages award case discussed above. Products liability cases and intentional torts are the only other case types with double-digit or greater mean ratios, where this pattern once again can be traced to a small group of cases. There are only seven products liability cases in the data set, and the products liability case with the highest ratio has a small compensatory damages award of $\$ 2,062$ 
coupled with a punitive damages award of $\$ 532,618$. It also appears to be quite reasonable for the intentional tort cases to have a higher ratio, which would be consistent with the Court's guidance with respect to the types of conduct that might merit deviations from the $1: 1$ ratio level.

The median ratios for the different case types reported in Table 1 are often very different from the median ratio across all case types of $0.66: 1$. The median ratio ranges from 0.23 to 1.45 . To the extent that the median is a reliable guide, a recommended ratio of 1:1 may be too high for some case types and too low for others. A recommended upper bound of 1:1 consequently would be a binding constraint at the median for two of the case types-premises liability cases and the 'other' tort category of cases.

The results at the lower percentiles reinforce the earlier observation about some punitive damages awards being quite small. The 5 th percentile and 25 th percentile results are quite striking in terms of how low their values are. At the 5 th percentile, the ratio is only 0.03 over all cases, indicating that in many instances the punitive damages awards are only token amounts. Even at the 25 th percentile, the ratios are very small. A case type to note particularly is medical malpractice. Despite being the focus of much tort reform discussion, the ratio at the 25 th percentile for medical malpractice awards is only 0.09. Ratios of this magnitude, and even the 25 th percentile across all cases of 0.23 , suggest that the punitive damages awards for these low ratio cases may have been symbolic amounts that are unlikely to create financial incentives that would alter behavior greatly or punish the defendant to a significant degree.

Suppose that these awards at the very low end of the ratio distribution are either not intended to serve the genuine purpose of punitive damages or are the result of an inability of jurors to set meaningful punitive damages amounts. Including them in the distribution of awards rather than dismissing them as being not pertinent lowers the observed median ratio value for the cases.

Matters become more complex at the upper end of the distribution. The ratio at the 95th percentile over all cases is 13.16 , with each of the case types having a ratio of at least $1: 1$. Several case types have double-digit ratios at the 95th percentile that would be above the single-digit upper bound in the State Farm case: 68.97 for intentional torts, 18.00 for slander/libel, 25.67 for the other tort category, and 10.00 for buyer plaintiff. To the extent that these case types involve the type of blameworthy behavior that the Court views as possibly meriting ratios in excess of $1: 1$, these cases may have a legitimate basis for a larger ratio, so presumably a cap of 1:1 would not be imposed in all these cases. 
A multiple regression analysis of the determinants of the ratio of punitive damages to compensatory damages illuminates which aspects of the cases are most influential in determining the ratio levels. Table 2 presents two regressions relating the log value of the ratio of punitive damages to compensatory damages to the log value of compensatory damages and the square of this term. ${ }^{37}$ This compensatory damages formulation that includes a quadratic term makes possible an exploration of potential nonlinearities in the relationship between the punitive damages to compensatory damages ratio and compensatory damages. Year indicator variables are also included in the regressions. The first column in Table 2 reports the results of a regression controlling only for the compensatory damages variables and for year. The second equation in Table 2 adds to the basic equation a comprehensive set of case characteristics that are available in all three years of data. The additional variables included in this equation are the total number of plaintiffs, the total number of defendants, and a series of indicator variables for jury trial, litigant pairs (individual v. individual, individual v. non-individual, non-individual $\mathrm{v}$. individual, with non-individual v. non-individual the omitted category), each of the case types listed in Table 1 (with motor vehicle tort the omitted category), bodily injury, and the 10 counties with a large number of cases.

Both equations indicate a significant negative effect of the log compensatory damages amount coupled with a significant positive squared effect. ${ }^{38}$ There is no significant temporal trend in the ratio controlling for compensatory damages amounts. The ramifications of these estimates for the relationship between the ratio of punitive damages to compensatory damages and compensatory damages are illustrated in Figure 1. Using the basic regression reported in column 1 of Table 2, the ratio of punitive damages to compensatory damages starts at a high value for cases with low levels of compensatory damages. The ratio declines as compensatory damages amounts rise. At a compensatory damages value of $\$ 8,100$, the log of the ratio drops below 0 , which in turn implies that the ratio is below 1.0. For the very low compensatory awards below this amount, the predicted ratio is above 1.0. The log of the ratio reaches its minimum value

\footnotetext{
${ }^{37}$ The regressions include all 517 punitive damages awards. Excluding the motor vehicle tort case with a ratio of 5,000 and a log ratio value of 8.52 has a modest effect on the coefficients and does not alter the overall relationships. Comparable regressions in which the dependent variable is the ratio rather than the log of the ratio explain very little of the variation.

${ }^{38}$ Unless noted otherwise, all effects discussed below are statistically significant at the 10 percent level or higher. Table 2 reports coefficients and standard errors, as well as indicators for significance at the 1 percent, 5 percent, and 10 percent levels.
} 
Table 2. Regression of Log(Punitive Damages/Compensatory Damages) on Case Characteristics

(1)

$(2)$

Log compensatory damages

$-1.349^{\star \star}$
$(0.154)$
$0.048^{\star \star}$
$(0.007)$

$-1.303^{\star \star}$

Log compensatory damages squared

(0.007)

$(0.156)$

Total number of plaintiffs

$(0.007)$

Total number of defendants

$0.147^{\star \star}$

(0.053)

Jury trial

0.008

$(0.033)$

Individual v. individual

$-0.242$

(0.240)

Individual v. non-individual

0.150

(0.312)

Non-individual v. individual

$0.533+$

(0.281)

$-0.448$

(0.510)

Premises liability

0.462

Products liability

(0.418)

Intentional tort

1.281

(0.798)

$0.546+$

(0.308)

Medical malpractice

0.318

Professional malpractice

(0.539)

Slander/libel

$-0.512$

(0.619)

0.717

(0.591)

Other tort

$0.935^{\star}$

(0.415)

Fraud

0.484

(0.457)

Seller plaintiff

$-0.063$

(0.533)

Buyer plaintiff

0.385

(0.468)

Employment contract

Lease

0.136

(0.678)

Other contract

$1.193^{\star}$

(0.582)

Other property

0.195

(0.792)

Bodily injury

Year $=1992$ 
Table 2. Regression of $\log ($ Punitive Damages/Compensatory Damages) on Case Characteristics (continued)

(1)

(2)

\begin{tabular}{lcc}
\hline Year $=1996$ & 0.057 & -0.300 \\
& $(0.209)$ & $(0.231)$ \\
Constant & $8.181^{\star \star}$ & $7.434^{\star \star}$ \\
Adjusted R-squared & $(0.854)$ & $(0.973)$ \\
& 0.20 & 0.24 \\
\hline
\end{tabular}

Data source: Authors' calculations based on the Civil Justice Survey of State Courts for the years 1992, 1996, and 2001. The sample is comprised of 517 cases where the plaintiff won and compensatory and punitive damages were awarded. All values are weighted by sample weight provided for the data year. The omitted categories are: motor vehicle tort and non-individual v. non-individual litigant pair. Indicator variables for 10 counties and indicator variables for missing values of number of plaintiffs or defendants and for litigant pair are included in the regression, but these coefficients are not reported. Standard errors in parentheses. + significant at $10 \%$; ${ }^{*}$ significant at $5 \% ;{ }^{\star \star}$ significant at $1 \%$.

for a compensatory damages level of $\$ 1.28$ million. The subsequent upward trend in the ratio affects few cases, as less than 10 percent of the sample of punitive awards have compensatory damages values of at least $\$ 1.28$ million. Only for a compensatory damages amount of at least $\$ 218$ million does the log of the ratio become positive. No cases in the sample are in the range where the predicted log of the ratio returns to being positive.

The results in Table 2 have a second principal implication. Most of the variation is accounted for by the compensatory damages variables. The adjusted R-squared value increases from 0.20 to only 0.24 after the inclusion of a very extensive set of case characteristic variables. ${ }^{39}$ Furthermore, the coefficients on the compensatory damages variables are very similar in the two regressions, which is consistent with the generally low individual correlation between compensatory damages and the additional variables calculated for this sample..$^{40}$

In terms of predicting the level of the ratio of punitive damages to compensatory damages, the dominant factor is the relationship that is established between punitive damages and compensatory damages. Other possibly pertinent influences such as the locale, the type

\footnotetext{
${ }^{39} \mathrm{~A}$ test of the joint significance of the additional variables included in the regression reported in column 2 but not column 1 yields $\mathrm{F}=1.65, \mathrm{p}=0.015$. Thus, the additional variables are jointly significant at the 5 percent level but not at the 1 percent level.

${ }^{40}$ Specifically, the largest pairwise correlation with the log of compensatory damages and the additional variables is with intentional tort, with a correlation coefficient of -0.176 .
} 
Log (Punitive damages/ Compensatory damages)

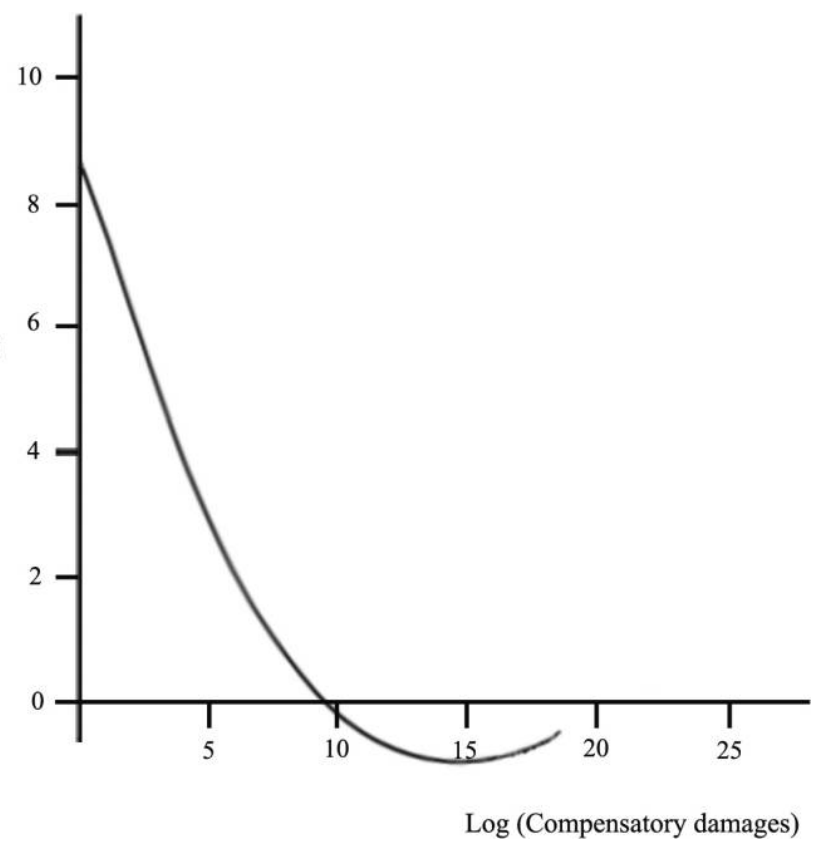

Figure 1. The Relationship between Predicted Log(Punitive Damages/ Compensatory Damages) and Log(Compensatory Damages)

of case, the characteristics of the parties involved, and whether the case involved bodily injury, have a small independent effect on the ratio. Examination of the results in the second column of Table 2 indicates which case characteristics have a significant influence. The number of plaintiffs in the case has a positive and significant effect on the ratio. In addition, a litigant pair that involves an individual filing a claim against a non-individual has a positive effect that is significant relative to the omitted category of non-individual v. nonindividual litigant pairs.

Relative to the omitted category of motor vehicle tort, several of the case types have a positive effect on the ratio of punitive damages to compensatory damages. These include: products liability (marginally significant $\mathrm{p}=0.109$ ), intentional tort, other tort, employment contract, and other contract. The effects for the first three tort groups are consistent with the overall statistics reported in Table 1, which indicate high ratios at the 95th percentile of these groupings. Bodily injury cases do not have a significant effect on the ratio. The high ratio for intentional torts is in line with the exceptions noted by the Court, but the reasons for all the other case type effects cannot be determined in the absence of information that describes the charac- 
teristics of the case more completely, such as a discrepancy between the harm and the level of compensatory damages.

The ultimate effect of Exxon Shipping Co. V. Baker on punitive damages will depend on the extent to which the Court's guidance serves as a ceiling rather than as anchor. In the punitive damages sample from the CJSSC data, there are 187 cases with ratios above 1:1. If these cases had ratios of $1: 1$, the average punitive damages award of $\$ 6,332,246$ would be reduced to $\$ 2,023,431$. The gross reduction in punitive damages from imposing an upper bound on these cases would be $\$ 805.7$ million. For the thirteen cases for which the ratio is already $1: 1$, the average punitive damages award of $\$ 117,529$ would be unaffected. The 317 cases with ratios below 1:1 would increase their punitive damages award from $\$ 298,179$ to $\$ 871,911$ if the $1: 1$ ratio serves as a target anchor. There are consequently more cases that would experience an increase in punitive damages awards than a decrease if a 1:1 ratio became the norm. However, because of the skewed distribution of award values, the savings from capping large awards exceed the increased costs of $\$ 181.9$ million from boosting award levels. The net savings from having a 1:1 target for these cases is consequently $\$ 623.8$ million, or about one-fourth less than the gross savings.

\section{VI.CON CLUSIO N}

In their quest to address the perceived problem of unpredictability of punitive damages, the U.S. Supreme Court adopted a mathematical approach. The main matter of interest for the Court is not the level of punitive damages, but rather is the ratio of punitive damages to compensatory damages in the case. That there should be concern with the relationship between these two damages components is not unreasonable, and is in fact embodied in standard law and economics theory of punitive damages. From the standpoint of perceived fairness, the idea that punitive damages for retributive purposes should bear some relationship to the harm, which usually is reflected in the compensatory damages amount, is quite appealing and is embodied in legal rules such as those pertaining to treble damages.

Ultimately, the decision relies on available statistical evidence as the justification of the approach. Why current awards provide any reliable basis for setting punitive damages guidelines is never justified by the Court and is inconsistent with the view of the Court and the academic literature suggesting that jury behavior is unpredictable. Because the median ratio is about 0.65 in some studies, chiefly drawing on samples of state court cases, the Court views a 1:1 ratio as a fair upper limit. However, the underlying statistical support for 
using the 1:1 ratio as a guideline is not compelling. While the median ratio is one statistic, there are other values, such as different percentiles of the distribution or the mean, that are also statistical measures of aspects of the distribution of punitive damages to compensatory damages ratios. Moreover, the median of this ratio will tend to be smaller than the mean value even if punitive damages levels are set appropriately because the distribution of the ratio of punitive damages to compensatory damages is truncated from below.

Somewhat curiously, the Court placed greatest reliance on the median ratio in the Civil Justice Survey of State Courts data. However, detailed examination of these data indicates that the high ratios of punitive damages to compensatory damages are due primarily to cases with very small compensatory awards, which are the types of cases that the Exxon guidelines might exempt. Cases with larger stakes in excess of $\$ 8,100$ in compensatory awards have average predicted ratios below 1.0 for every case in the CJSSC sample. A substantial fraction of the punitive damages awards in the CJSSC sample involve token amounts that surely were only of symbolic value. If the Court wishes to rely on empirical evidence pertaining to highly variable and substantial punitive damages awards, a better reference point might be the sample of blockbuster punitive damages awards of at least $\$ 100$ million. That sample has highly variable ratios of punitive damages to compensatory damages, but also has median ratio values in excess of 1.0. If these blockbuster cases are true outliers that are the result of faulty punitive damages judgments, then they do not serve as a sensible reference point. However, if the large awards and the high ratios have a sound basis, then the factors that led to such awards should be examined more fully before dismissing their ratio in excess of 1.0 as being inappropriate.

The U.S. Supreme Court's decision to establish a numerical ratio guideline will have complex effects on future cases. In effect, this decision may establish the 1:1 ratio as a focal point or as an anchor for future jury deliberations. To the extent that the 1:1 ratio serves as both a ceiling and a floor for punitive damages, more cases will experience an increase in punitive damages levels than will experience a decrease. On balance, the total punitive damages values in the economy will be reduced because the large awards will be reduced by a greater amount than the small awards will be increased. However, the absence of a stronger theory of punitive damages to provide guidance for setting punitive damages amounts will tend to reduce the restraining effect that the Court intends and will tend to homogenize punitive damages values, possibly limiting their deterrent effect and case-specific relevance. 